\title{
THE JEWISHNESS OF JOHN'S USE OF THE SCRIPTURES IN JOHN 6:31 AND 7:37-38
}

\author{
Glenn Balfour
}

\begin{abstract}
Summary
Two of some eighteen citations of scripture in the Fourth Gospel are examined in detail in order to demonstrate that John's use of the Old Testament is based on received Jewish exegetical methods. His treatment of scripture is essential to major facets of his gospel, namely his christology and polemical thrust.
\end{abstract}

\section{Introduction}

That Judaism and its scriptures directly influence the Fourth Gospel is nothing new. Sixty years ago Dodd wrote:

Jewish terms and usages are sometimes explained in the Fourth Gospel, but knowledge of Judaism is assumed. We are hardly through the Prologue when we meet with priests, Levites and Pharisees, a reference to Elijah, and a quotation from Isaiah, all without any explanation. There are unexplained allusions to Rabbinic doctrines, and interpretations of the Old Testament. ${ }^{1}$

Our intention here is to develop the insights of Dodd and others concerning the essential Jewishness of the author of the Fourth Gospel2 by means of a consideration of his use of the Jewish scriptures.

${ }^{1}$ C.H. Dodd, 'The Background of the Fourth Gospel', BJRL 19 (1935) 32943 , here 334.

${ }^{2}$ We refer to the author of the Fourth Gospel as 'John', with no reflection on number or gender. 
Many scholars have paved the way for this. Barrett assimilated a broader view of the Jewish influence on the Fourth Gospel, finding that the whole body of the Old Testament formed a background, or framework, upon which the new revelation rested'.3 Glasson's seminal work demonstrated a vast range of Mosaic imagery in the Fourth Gospel, especially in its christology, and highlighted a considerable body of rabbinic parallels with John's Old Testament imagery. ${ }^{4}$ Reim cogently argued that many significant Johannine developments of the Christian tradition evinced an Old Testament background. 5 Freed made the first detailed investigation of John's explicit references to the Old Testament. 6

In what follows, consideration will be given to two of John's eighteen Old Testament quotations $(6: 31 ; 7: 37-38)$ in which the Jewishness of John's use of Old Testament scripture is clearly to be seen. It is our belief that these test cases provide important examples of how John uses the Old Testament based on received Jewish exegetical methods.

\section{Bread out of Heaven: John 6:31}

This quotation, on the lips of the multitude and a cue for Jesus' bread of life discourse, is unique to John in the New Testament. There is little to suggest that he takes it from a testimonium. The introductory formula occurs elsewhere in the New Testament in John 12:14 (cf. Lk. 4:17), John's preferring it to the

${ }^{3}$ C.K. Barrett, 'The Old Testament in the Fourth Gospel', JTS 48 (1947) 155-69, here 168.

4T.F. Glasson, Moses in the Fourth Gospel (SBT 40; London: SCM, 1963). Dodd had not shown that comparing rabbinic material-whose earliest written source, the Mishnah, is later than $200 \mathrm{CE}$-with the Gospel is legitimate.

${ }^{5} \mathrm{G}$. Reim, Studien zum Altestamentlichen Hintergrund des Johannesevangelium (SNTSMS 22; Cambridge: CUP, 1974).

6E.D. Freed, Old Testament Quotations in the Gospel of John (NovTSup 11; Leiden: Brill, 1965). His methodology has recently been reapplied by B.G. Schuchard, Scripture within Scripture (SBLDS 133; Atlanta, Georgia: Scholars, 1992). 


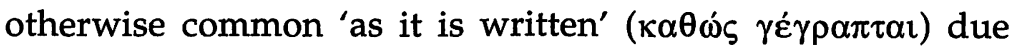
partly no doubt to his predilection for periphrastics.

The quotation does not precisely agree with any Old Testament passage but it is close to Exodus 16:4,15, Nehemiah 9:15 (LXX 2 Esd. 19:15), and Psalm 78:24 (LXX 77:24). 7 The LXX provides an adequate translation of all four passages, especially Ps. 78:24b. ${ }^{8}$ Exodus 16:4 differs from John in word

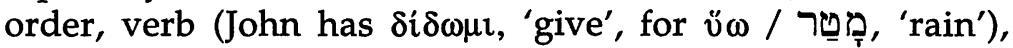

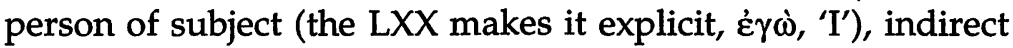

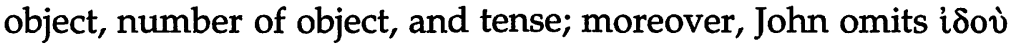

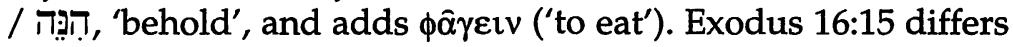
in sentence construction, person of subject (the MT and LXX make it explicit, יהוז / אv́plos, 'Lord') and indirect object;

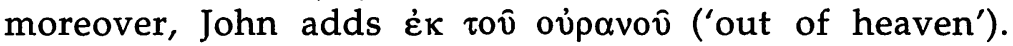
Nehemiah 9:15 differs in definiteness ('heaven' in the LXX and MT is anathrous), person of subject; moreover, John does not

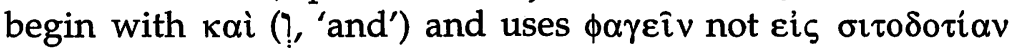

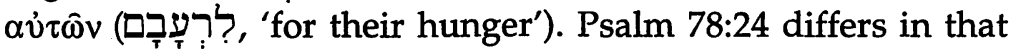

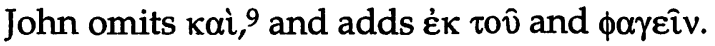

This leads some to deem his text a conflation of several or all of these. The latter alternative with little preamble is Goodwin's conclusion, which he uses as evidence for John's peccadillo for citing scripture from memory even when, as here, explicitly invoking its authority. 10 Freed gives a considerably longer and more convincing argument, that the text is an admixture of the Hebrew and LXX of Exodus 16:4 and Psalm 78:24 while showing affinity to Tg. Ps.J. on Exodus 16:15.11 Becker argues that it is a free allusion to all four passages, as well as Wisdom of Solomon 16:20.12 Others deem it impossible to trace the quotation's source(s) at all.

${ }^{7}$ We cite the pointed MT and LXX B unless otherwise stated.

${ }^{8}$ The plural ăp a collective.

${ }^{9}$ Cod. R. also omits it from the LXX.

${ }^{10}$ C. Goodwin, 'How did John treat his Sources?', JBL 73 (1954) 61-75, esp. 67-68.

11Freed, Quotations, 15.

12J. Becker, Das Evangelium nach Johannes (2 vols., ÖTK 4/1-2; Gütersloh: Mohn, 1979/81) I, 204. Marie-J. Lagrange, Evangile selon 
While it is by no means atypical for John to conflate quotations, others opt for one of these four passages, often Psalm 78:24, sometimes giving one or more of the others a secondary role (usually Ex. 16:4/15).13 Virtually every possible combination has been suggested, even that it is the peculiar product of a Johannine School.14 Richter attempts to break the mould by proposing that the source is not Jewish scripture at all but a Jewish, anti-Christian haggadah, which presents Moses as the giver of the manna and which John uses as his point of departure. 15 This is not without its merits, but as Richter himself concedes, it only pushes the problem backwhat scripture was the haggadah based on, a scripture which John incorporates into his text? He concludes that it was a targumic, midrashic or free quotation from Exodus 16:4/15.16

Menken concedes that 'bread', being plural in Exodus 16:4 (LXX) while singular in John 6:31, 'could be due to the use, by the fourth evangelist, of the Hebrew text, or of a corrected Greek translation',17 but this argument is not cogent. The cumulative evidence is heavily in favour of John using the LXX, while the Greek variants are manifestly due to influence from

Jean (Paris: Gabalda, 1948) 175, had long noted the significance of Wis. 16:20. John's presenting Jesus as the Bread which comes out of heaven certainly echoes the statement in Wis. 16:20 that the manna is 'angels' food...prepared bread from heaven'. This statement seems to pre-empt the later belief that the manna existed eternally in heaven (cf. b. Hag 12b; Tg. Ps. J. on Ex. 16:4).

13S. Pancaro, The Law in the Fourth Gospel (NovTSup 42; Leiden: Brill, 1975) 457, $461 \mathrm{n}$. 29, for example, argues that Ps. 78:24 is the likely source but does not exclude, in order of probability, Ne. 9:15 and Ex. 16:5.

${ }^{14} \mathrm{G}$. Richter, 'Die alttestamentlichen Zitate in der Rede vom Himmelsbrot, Joh 6, 26-51a', in J. Ernst (ed.), Schriftauslegung. Beiträge zur Hermeneutik des Neuen Testaments und im Neuen Testament (München, etc.: Schöningh, 1972) 193-279 (repr. in idem, Studien, 199265) here 197-208, lists most of the suggestions.

15Ibid, 208-31.

16Ibid, 248-50. M.-E. Boismard et al., Synopse des Quatre Evangile en français 3: L'Evangile de Jean (Paris: Les Editions de Cerf, 1977) 196, argues that the source is a targum on Ex. 16:4/15b in which מֶמְטִיר) from v. 4 is rendered, 'to make come down'.

17M.J.J. Menken, "The Provenance and Meaning of the Old Testament Quotation in Jn 6:31', NovT 30 (1988) 39-56, here 42. 
him (cf. LXX B \& Ps. 69:10a).18 While some of the other differences between Exodus 16:4/15 and John 6:31 are

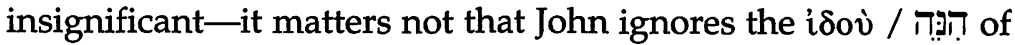
v. 4-neither verse alone suffices as his source. But what if taken together? John could then be supplementing v. 4 with the singular $\alpha$ o $\rho \tau$ ov of $v$. 15, as those scholars who opt for an Exodus source invariably suggest. Borgen, who has thoroughly explored the background of John 6:31-58, suggests this since the passage can then be seen as based on a homily in the haggadic tradition in which a main text from the Torah is followed by a subordinate one from the Prophets or Writings (here Jn. 6:45). This best explains the exegesis involved in John 6:32-33,36, and provides a context in which 'bread' and 'murmuring' both occur. ${ }^{19}$ Reim argues that the crowd give a

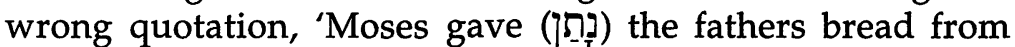
heaven', which Jesus corrects in John 6:32: 'God gives (נפתן) you the true bread from heaven'. 20

Menken's counter that 'the introductory formula suggests that a specific O.T. text is quoted'21 is unfounded; John frequently appends introductory formulas to conflate quotations ( $c f$. 7:37-38.; 12:13,15; 19:36). Some differences, however, remain unexplained: word order, the subject (explicit in LXX of both passages) and the indirect object. It is somewhat anomalous for Reim to argue that Exodus 16:4/15 is being misquoted, especially since the 'misquotation' looks remarkably like Psalm 78:24b. Besides, John nowhere implies what Reim suggests; Jesus might question the crowd's exegesis, but not their accuracy.22 Borgen too has no warrant to suppose that John wants 6:31-58 to fit into the homiletic pattern he suggests; not only are there plenty of other patterns that it can be made

\footnotetext{
${ }^{18}$ Menken tentatively concedes the latter point ('Provenance', $42 \mathrm{n} .9$ 9).

${ }^{19}$ See P. Borgen, 'Observations on the Midrashic Character of John 6', ZNW 54 (1963) 232-40, esp. 239; idem, Bread from Heaven (NTSup 10; Leiden: Brill, 1968, 1981) 38, 40-41; cf. 51-52, 65-66.

20Reim, Studien, 12-15; see also 90, 96.

${ }^{21}$ Menken, 'Provenance', 42, cf. 40; similarly, Schuchard, Scripture, 34.

${ }^{22}$ Menken, 'Provenance', 46, says as much, but then uses a similar defence for Ps. 78:24.
} 
to fit, ${ }^{23}$ such patterns were not as fixed as Borgen implies.24 More significantly, the exegesis in John 6:32-33 is equally applicable to the Psalm, and the motif of murmuring is also found (albeit without literal likeness to Jn. 6:41,43) in the Psalm (vv.17-22, 32-43) and in Nehemiah 9:16-19.

Of the differences between John 6:31 and Nehemiah 9:15, which Schlatter and Lightfoot favour as the source,

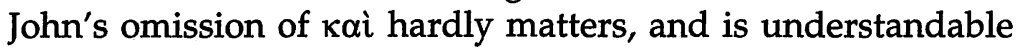
since he would be quoting only one half of a parallelism (he has already done the same thing in 2:17 and will do so again in 19:37; cf. 6:45), and he may have considered $\phi \alpha \gamma \varepsilon i ̂ v$ to be a valid alternative to $\varepsilon i \varsigma \sigma \tau \tau o \delta o \tau i \alpha v \alpha v i \omega \hat{v} ; 25$ as Menken notes, the expressions have a similar meaning and are at the same place in the sentence. Yet beside the fact that John quotes from Nehemiah nowhere else and from the Psalms frequently, it remains that he adds the article $\tau o v$ and alters the person of the subject. It is for these reasons that other scholars who wish to cite a specific text often cite Psalm 78:24b.26

While Menken offers a redactional investigation of John's deviations from the Psalm, all three differences between the Psalm and John 6:31 can be readily explained. John omits кoi since, as with Nehemiah 9:15, it becomes redundant as

${ }^{23}$ A. Finkel, The Pharisees and the Teacher of Nazareth (AGSU 4; Leiden-Köln: Brill, 1974) 149-55, 158-59, considers Jn. 6:30-59 to be a 'proem homily', in which the text of the pericope (Ex. 16) is linked with a proem text from the Writings (Ps. 78:24); both texts are then explained and the homily closes with words of comfort. B. Lindars, The Gospel of John (New Century; London: Oliphants, 1972) 250ff., presents the passage as a synagogue homily and the primary source as Ps. 78:24. For a discussion of Borgen's and Finkel's propositions, see Richter, 'Zitate', 232-40.

24Menken's point ('Provenance', 43), that since the quotation is spoken by the crowd rather than by John it is not bound by any homiletic pattern, however, is not valid. The crowd, as with all the dramatis personae in the Gospel, serve John's wider message. G. Richter, 'Zur Formgeschichte und Literarische Einheit von Joh 6:31-58', ZNW 60, (1969) 21-54, gives an exceptionally intricate rebuff of Borgen's analysis, based on source-critical grounds.

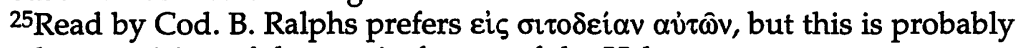
a later revision of the text in favour of the Hebrew רֶָָ.

${ }^{26}$ Schuchard, Scripture, 34-38, continues this trend. 
soon as the second half of the parallelism is isolated. He may

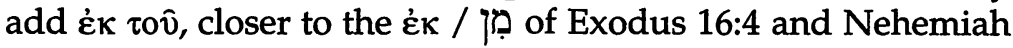
9:15 than the $\tau 0$ vo (Hebrew construct) of Psalm 78:24 (Ex. 16:4 LXX also has $\tau 0 \hat{v})$, due to secondary influence from one or both of these sources, 27 or partly, at least, due to the influence of Psalm 77:26a ('he loosed the east [wind] out of heaven', $\dot{\varepsilon} \xi$ ovjpavov) only three lines away. Either way, it is entirely Johannine and may be nothing other than redaction Since Jesus does come down from heaven, it is not enough to say that he,

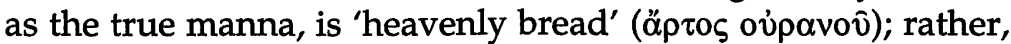

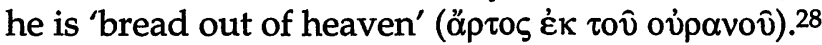

As for John's adding $\phi \alpha \gamma \varepsilon \hat{\imath} v$ (the most significant difference), while it occurs (without reference to heaven) in Exodus $16: 15$, it is somewhat inconsistent to have two 'secondary' influences from here and yet retain the Psalm's primacy. John in fact takes it from the end of Psalm 77:24a LXX, choosing not to quote the first line of the parallelism. Barrett is hardly unequivocal in his regard for this possibility, ${ }^{29}$ but this is without reckoning with some Jewish evidence which suggests that John could do such a thing deliberately.

The twenty-second of the thirty-two 'rules of interpretation' compiled by R. Eliezer b. Jose ha-Gelili30 deemed such transferring of words from one half of a parallelism to the other perfectly legitimate. There is uncertainty over the date of the completed rules of interpretation, but the twenty-second was in use at least by the

27Even Menken, 'Provenance', 44, despite his statement over the introductory formula, concedes this point, opting for Ex. 16:4.

${ }^{28}$ So R. Schnackenburg, Das Johannesevangelium (HTKNT; Freiburg, etc.: Herder, 1971; tr. 1980) I, 104; II, 54. Menken, 'Provenance', 44, prefers this explanation, yet not necessarily exclusively.

${ }^{29}$ C.K. Barrett, The Gospel According to John (London: SPCK, 1978) 289: it is 'perhaps in favour of the Psalm'.

${ }^{30}$ The rule is: 'a sentence to which its parallel brings evidence'. See W. Bacher, Die exegetische Terminologie der jüdischen Traditionsliteratur, I: Die bibelexegetische Terminologie der Tannaiten (Leipzig, 1899; repr. Hildesheim: Darmstadt, 1965) 39-40; H.L. Strack \& G. Stemberger, Introduction to the Talmud and Midrash (Edinburgh: Clark, 1991) 31. 
second half of the second century. ${ }^{31}$ It is only reasonable, then, that here (as in 1:23) John applies an earlier oral version. His motivation for this is not difficult to find: it is to highlight Jesus' monologue in 6.35ff. His thoroughgoing christological hermeneutic ( $c f .1$ Pet. 1:10ff.) explains this handling: it merely makes explicit what the psalmist is actually saying. ${ }^{32}$

With Psalm 77:24b LXX as John's primary source, everything falls into place. Only now is his translation of the singular ö $\rho \tau$ c s explained, since the Psalm provides the only instance in the LXX where this happens (the usual translation is $\sigma i \tau(\varsigma)$. More significantly, only now is his inferred shift in subject from God to Moses possible, since only in the Psalm is God as subject referred to by means of a third person verbal form, 'he'. 33 Hence Moses could be considered the subject of 'he

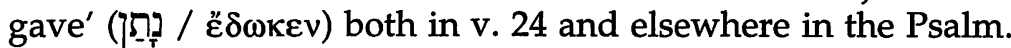
With the rising importance of the figure of Moses in Second Temple Judaism, such transference was not only possible but likely. There is also the fact, understated by Freed, that of our

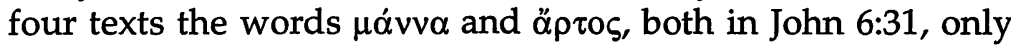
occur together in Psalm 77:24 LXX.34

${ }^{31}$ R. Nathan uses it in Mek. Kaspa 2, to exegete Ex. 23:1. See Strack \& Stemberger, Introduction, 31. Similarly, in idem, Einleitung in Talmud und Midrasch (München: O. Beck, 1976) 106: 'Ps 38:2 ergänze ל vor

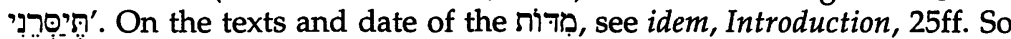
J.W. Doeve, Jewish Hermeneutics in the Synoptic Gospels and Acts (Assen.: van Gorcum, 1954) 61, dates them from between 130-160, supplementing and extending the thirteen rules of $\mathrm{R}$. Ishmael, even though 'Jishmael and Eliezer $b$. Jose the Galilean did no more than continue to build upon the foundation laid by Hillel'.

32Paul does a similar thing when, assured that man can live apart from works of the Law, he quotes Ps 143:2 as saying, 'no flesh will be justified by the works of the law' (Rom. 3:20; Gal. 2:16).

33So Menken, 'Provenance', 54-55, who also offers a number of other Jewish parallels for the transferring of subject; also Schuchard, Scripture, 45-46.

${ }^{34}$ Freed, Quotations, 15. A.T. Hanson, The Prophetic, Gospel (Edinburgh: Clark, 1991) 84, somewhat confusedly sees the 'basic text [as] certainly Exodus 16 ' but that 'John is probably paraphrasing' Ps. 77:24 LXX, noting that John could take v. 22 of the Psalm as a parallel to oi 'Iov $\alpha$ îou, and v. 29 as a 'preshadowing' of the feeding of the 5,000 just narrated. G. Geiger, 'Aufruf an Rückkehrende. Zum Sinn des Zitats von Ps 78:24b in Joh 6:31', Bib 65 (1984) 449-64, like Menken and Barrett, 
While John does not have to have any one scripture in mind, the evidence suggests that he does. This is not necessarily to say, however, that he is not aware of other scriptures, including any or all of the other three cited here, Hebrew versions included, or the relevant targumic material, nor that they do not play a part in the forming of his version. ${ }^{35}$

John's setting for the quotation reveals his familiarity not only with Jewish scriptural motifs and imagery but also with contemporary Jewish exegeses of them. Borgen has given much greater precision and significance to this area, pointing out two midrashic features common to Philo, John and the Palestinian midrash: 'the systematic paraphrase of words from Old Testament quotations and fragments from haggadic traditions, and the use of a widespread homiletic pattern'. ${ }^{36}$ Borgen's demonstration of the quotation's Jewishness is invaluable, but he is too narrow when he gives John's purpose in employing the midrashic method as simply being to counter docetism. ${ }^{37} \mathrm{John}$ uses it to present Jesus as 'the bread of life' ( $\dot{0}$

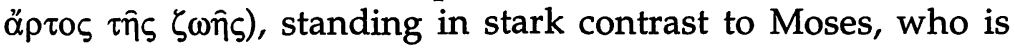
presented by the Jewish crowd as having provided the manna which their fathers ate in the wilderness and died. ${ }^{38}$

presents Ps. 78:24 as the sole source, demonstrating that large parts of Jn. 6 are based on the Psalm.

35It is perhaps significant that Ne. 9:20 brings together three Johannine terms: your spirit... you gave... and you did not withhold your manna...

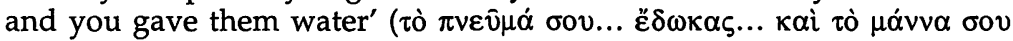

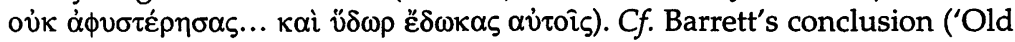
Testament', 168). Many, however, prefer a combination of Ex. 16:4/15 and Ps. 78:24; $c f$. Freed, Quotations, 12ff.; J.N. Aletti, 'Le Discourse sur le Pain de Vie: Jean 6, Problèmes de Composition et Fonction des Citations de l'A.T.', RevScRel 62 (1974) 169-97, here, 180, 187-89, and R. Schnackenburg, 'Zur Rede vom Brot aus dem Himmel: eine Beobachtung zu Joh 6:52', BZ 12 (1968) 248-52, who sees reference to the whole exodus background.

36Borgen, Bread, 59. We remain unconvinced of the homiletic pattern. 37J.L. Martyn, History and Theology in the Fourth Gospel (NY, Evanston, Ill.: Harper \& Row, 1968, rev. 1978) 108-19, is not happy with Borgen here either.

38So Menken, 'Provenance'. Hanson, Prophetic, 85, is too hesitant; the stand-off between Moses and Jesus, the pre-existent Logos, is clearanything Moses can do Jesus can do better. Contra C.H. Dodd, The 
Attestation that Moses performed the miracle is not found anywhere before the end of the third century $C E$, and is certainly not entertained in Jewish scripture, including Psalm 78:24b. Only with $b$. Sota 35a (cf. Sifre 339; Petirat Mosheh) ${ }^{39}$ is Rabbah (third to fourth century CE) reported to have put in Caleb's mouth (in an explanation of Nu. 13:30) the words, ' $\mathrm{He}$ [Moses] brought us out of Egypt, divided the Red Sea for us and fed us with manna'. Yet since this is what is being expressed by the crowd in John 6:31, this development of the Moses figure must have been extensive at the end of the first century CE, later suppressed by rabbinic Judaism, finally reemerging in the third to fourth century. 40 Moses can only be assumed the subject of Psalm 78:24 once he is considered as having power over nature and the giver of nature.

While the word 'manna' does not appear in the Exodus

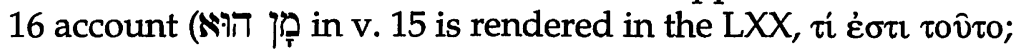
'What is it?'), some of the passages where it does appear (Nu. 11:6; Dt. 8:3; Jos. 5:12; Ne. 9:20; Ps. 78:24) show that the term was already being used as an expression for moral and spiritual teaching. This tendency to 'spiritualise' the manna was developed by Philo who in a number of places allegorises it. ${ }^{41}$ The real development, however, was in its becoming a symbol of the new (messianic) age. So, for example, the Mekilta on Exodus 16:25 (ויסע, \$5) reads, 'You will not find it [the manna] in this world but you will find it in the world to come' .42 While the rabbinic statements to this effect are of

Interpretation of the Fourth Gospel (Cambridge: CUP, 1960) 335, John does not apply here the association between bread and Torah.

${ }^{39}$ All three texts are in B.J. Malina, The Palestinian Manna Tradition (AGSU 7; Leiden: Brill, 1968) 87-88.

40So Menken, 'Provenance', 47-48; D. Daube, 'The Earliest Structure of the Gospels', NTS 5 (1958-9) 174-87, here 178 n. 2; Malina, Manna, 88 n. 3. Cf. H.M. Teeple, The Mosaic Eschatological Prophet (JBLMS 10; Philadelphia, PA: SBL, 1957) 68.

${ }^{41}$ Esp. Philo, L.A. 3.169-76, where 'food of the soul' (

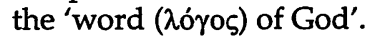

42J.Z. Lauterbach (ed.), Mekilta de-Rabbi Ishmael (Philadelphia: Jewish Publication Society of America, 1976) II, 119. Cf. H.L. Strack \& P. Billerbeck, Kommentar zum Neuen Testament aus Talmud und 
course not early, this general parallelism between the period of the Exodus and the end times is at least as old as DeuteroIsaiah, hence the idea that in the end time the manna will again fall from heaven may date back to the end of the first century CE (cf. Rev. 2:17; 2 Bar. 29:8).43

There is yet another twist to this development in that the last redeemer became paralleled with the first, Moses, because among other things he too will provide manna from heaven (cf. Eccles. R. I.9).44 The evidence, albeit marginally earlier in Cant. R. 2,9,3 (R. Isaac b. Merion, c. $280 \mathrm{CE}$ ), is late,45 but John 6 (especially vv. 32-33) again invites us to extrapolate. These eschatological associations with Moses too were extensive at the end of the first century $\mathrm{CE}$, only to be suppressed until the third and fourth century as a result of 'Jewish opposition against the Christian deification of their Messiah, Jesus, whom the Christians saw as parallel to Moses, or-more generally-Jewish opposition to anything that looked like a "second God"'. 46 Indeed, John's Moses polemicunlike the Christ, to whom he bore witness, Moses was only a man and had never seen the Father-reciprocates this sentiment. John, then, is familiar with this extensive Jewish development of Moses, especially in terms of the manna miracle, and puts it to good use here in his christological treatise, encapsulating a wide range of Jewish imagery and scriptural exegesis.

However, while Martyn underplays the Moses imagery in John's feeding of the 5,000, he rightly comments:

Midrasch (München: O. Beck, 1922-8); A. Schlatter, Der Evangelist Johannes (Stuttgart: Calwer, 1975) 172-73.

432 Baruch may not be far from $100 \mathrm{CE}$; see D.S. Russell, The Method and Message of Jewish Apocalyptic (London: SCM, 1964) 64. Also cf. Sib. Or. 7:148-49 and fragment 3:46-49.

${ }^{44} \mathrm{H}$. Freedman \& M. Simon (eds.), The Midrash Rabbah (London, etc.: Soncino, 1977) VIII, 33.

${ }^{45}$ Malina, Manna, 88 n. 3, adds others texts. A number of earlier Christian texts also contain the idea (e.g. Irenaeus, Fragm. 19), but as Menken, 'Provenance', 47 n. 25 suggests, these presumably derive it from the Gospel.

46Menken, 'Provenance', 48. For further support for the former, see Daube, 'Structure'; Malina, Manna. 
'The point of the sign is not the Moses-Messiah typology but rather God's gracious election'.47 The issue in John 6:31 is far bigger than midrashic exegesis of Jewish scriptures, Mosaic, eschatological or otherwise; instead, it concerns the role and identity of Jesus as the Christ. He, not Moses, is the messianic, eschatological figure who, like his Father, provides manna from heaven, by feeding the 5,000; he, the last redeemer, marks the inauguration of a new age; he himself becomes the bread that the Father provides. ${ }^{48} \mathrm{McHugh}$ summarises the homily on $6: 32$ as, 'my Father is at this moment giving you the true bread from heaven' ${ }^{49}$ It is this and the sign that points to it (cf. 6:26) that the crowd fail to see.

John does here with Jewish scripture what only someone thoroughly acquainted with Jewish forms of exegesis could do. Moreover, he presents his message in a way that only someone thoroughly acquainted with Jewish forms of exegesis could understand. 50

\section{Living Water: John 7:37-38}

The introductory formula and the quotation, spoken by Jesus at the Feast of Tabernacles, are both unique in the New Testament. Again, there is little evidence that John uses a testimonium. Lindars conveniently divides what Hanson describes as 'probably the most thoroughly discussed three verses in the entire Gospel' into three main areas of

\footnotetext{
47Martyn, History, 115 (his emphasis).

48See especially the word-play on מדּ̣ as 'what is it?' / 'who is he?'.

49J. McHugh, "In Him was Life': John's Gospel and the Parting of the Ways', in J.D.G. Dunn (ed.), Jews and Christians (WUNT 66; Tübingen: J.C.B. Mohr, 1992) 123-58, here 138.

${ }^{50}$ Borgen, Bread, provides a refreshing change when, instead of fragmenting the chapter, he traces, with a convincing use of Jewish texts (including Ex Rab. 25:2,6; Philo, Mos. 1.201f., 2.267; Mek. Ex 16:4; Petirat Mosheh), the same exegetical pattern through all of it. $C f$. Schuchard, Scripture, 38-45, on 6:28-59. It is not advisable to say, with McHugh, 'Life', 138, that 6:31-32 is 'the first example of the evangelist's "searching the Scriptures" to give a midrashic exposition of his faith in Jesus as the Christ, and the Son of God'.
} 
confusion. 51 The first is that of grammar. UBS4 places a full

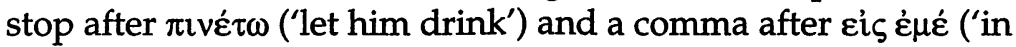
$\left.m^{\prime}\right)$ : in this way, the scripture is taken to refer to 'the one who

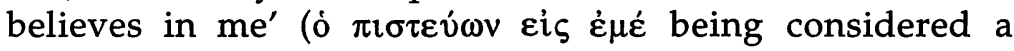
nominativus pendens resumed in $\alpha$ v่ $\tau 0 \hat{v}$, 'of him'),52 so that the rivers of living water flow out of the believer. The alternative is to place a comma after 'to me' ( $\pi \rho \rho \varsigma \varepsilon \varepsilon$ ) and a stop after 'to

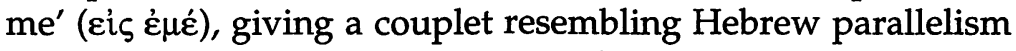
in prose. The scripture is now ambiguous: it is either this couplet, or, more likely and as with the former reading, what

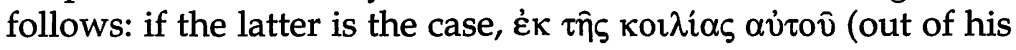
belly) refers to Christ or the believer or both.

Some draw attention to the parallelism as if that makes the alternative punctuation more likely, but this view is problematic. It may suggest an Aramaic original (so Brown and Barrett), 53 but this begs the question as to whether or not there ever was such an original-and judging by the unusual form of the scripture, this seems most unlikely. Moreover, not only is it at best imperfect and muddled (for example, the invitation to drink is better connected with 'if anyone thirsts' than with "the one who believes'),54 and thus hardly intentional, it is apparent that John dislikes using such parallelism anyway. Bultmann prefers the alternative punctuation because it is difficult to find an Old Testament text to satisfy the traditional punctuation, 55 but it is hard to see how in this respect his preference fares any better.

51Lindars, John, 296ff.; Hanson, Prophetic, 99.

52Barrett, Gospel, 326.

53S.H. Hooke, 'The Spirit Was Not Yet', NTS 9 (1963) 372-80, posits a Hebrew original.

${ }^{54}$ So Barrett, Gospel, 327; cf. Reim, Studien, 70. It is surprising that Barrett then agrees with E.C. Hoskyns, The Fourth Gospel (London: Faber \& Faber, 1940) 365-69, that both renderings make Johannine sense. G.D. Kilpatrick, 'The Punctuation of Jn 7:37-38', JTS 11 (1960) 34042 , unconvincingly renders the alternative, 'If any man thirst, let him who believes in me come and drink', while one Coptic manuscript

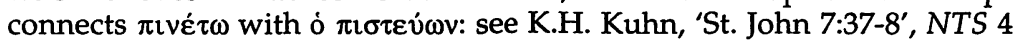
(1957) 63-65.

${ }^{55}$ R. Bultmann, The Gospel of John (Eng. trans.; Oxford: Blackwell, 1971) 303. He also notes the couplet's rhythm. More recently B.H. Grisby, "If any man thirsts': Observations on the Rabbinic Background 
Accordingly, the traditional punctuation seems preferable, and this coincides with textual evidence as well. The ancient authority for the alternative consists of some Western Fathers, the colemetry of the old Latin manuscripts $D$ and $\mathrm{E}$, a single Coptic manuscript, and a vague allusion in the Epistle of the Martyrs of Vienne. ${ }^{56}$ The majority of Greek Fathers support the traditional punctuation, however, as does $\mathrm{P}^{66}$ (c. $200 \mathrm{CE}$ ). This reading makes good sense theologically; 'as thirsty, a man is properly summoned to come and drink; as a believer, who has come and drunk, he can then be the subject of a statement'. 57 Moreover, this reading has the feel of John's literary style. 58 While Barrett accepts the traditional punctuation somewhat open-endedly, Lindars is right to be in no doubt. 59

The second area of difficulty for these verses is that of the quotation's source. If the punctuation issue is left openended, this is exacerbated since all three scriptural possibilities-the thirsty invited to come and drink, 60 living water flowing from the belly of the believer, living water flowing from the belly of Christ-can be paralleled in a general sense in the Old Testament. Isaiah 55:1 is but one of many texts to present God as a fountain of living water who supplies the needs of humanity. But with this issue resolved at least we can

of John 7, 37-9', Bib 67 (1986) 101-108, has supported the alternative punctuation, based on a passage in the Tosefta, as has Hanson, Prophetic, 99ff. J.D.G. Dunn, The Partings of the Ways Between Christianity and Judaism and their Significance for the Character of Christianity (London: SCM, 1991) 94, also assumes the couplet rendering, with 'From his belly shall flow rivers of living water' as the scripture.

56Eus. H. E. 5, i, 22. Moreover, as Barrett, Gospel, 327, states, 'the reference may be to $19: 34$, not to $7: 38 b^{\prime}$.

57Barrett, Gospel, 327.

${ }^{58}$ Quite apart from the parallelism issue, John is fond of casus pendens. C.F. Burney, The Aramaic Origin of the Fourth Gospel (Oxford: Clarendon, 1922) 63-65, counts twenty-seven in the Gospel.

${ }^{59}$ So too Reim, Studien, 57-70, and others, including Kohler, Allison, Loisy, Hodges, Bauer, Balagué, Miguens, Fee and Robert.

${ }^{60}$ As A.P. da Silva, 'Giovanni 7, 37-9', Salesianum 45.3 (1983) 575-92, considers the source to be Is. 55:1-3. Is. 55:1-3 is certainly being alluded to here. See Hanson, Prophetic, 113. 
be sure that the quotation refers to the believer.61 It is this 'scripture' that scholars tend to search for.

Most do not search very extensively. Barrett soon concedes that no one Old Testament text fits the quotation whatever reading is preferred and opts for an association of ideas. These include the rock struck by Moses (Ex. 17:1-7; Nu. 20:2-11), the prophecy of the stream flowing from the Temple (Eze. 47:1-8), and several texts involving 'living water' and/or invitations to drink (e.g. Is. 28:16;62 41:18; 43:20; 55:1-2). ${ }^{63}$ Freed too offers a large list of suggested influences, including 'several from Qumran Scrolls' and some from Old Testament Wisdom literature, ${ }^{64}$ as does Goodwin, especially Wisdom texts. 65 Since none of these passages are actually quoted and even together do not satisfactorily explain John's quotation, however, all three scholars come to similar conclusions:

61So J. Blenkinsopp, 'John VII. 37-9; Another Note on a Notorious

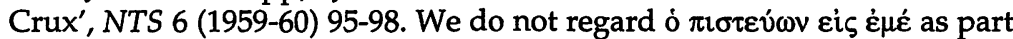
of the quotation, since John does not place the introductory formula in the middle of the quotation anywhere else. Either way it adds little to the meaning. For many, including Boismard, Costa, Schnackenburg and Hanson (in Prophetic, 113), the necessity that Jesus is the one out of whom the water flows is a determining factor in their opting for the alternative punctuation, though all these cited accept v. 38 as the scripture.

62Reim, Studien, 70ff., first proposed this as the primary source, based

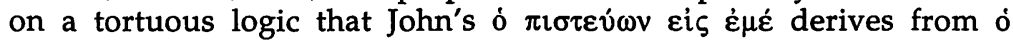
$\pi \imath \sigma \tau \varepsilon v \dot{v} \omega \nu \dot{\varepsilon} \pi$ ' $\alpha \dot{v} \tau \hat{\varphi}(\mathrm{LXX})$, referring to the struck rock.

63Barrett, 'Old Testament', 156ff.

64Freed, Quotations, 21-22. Freed deems Pr. 18:4 LXX the 'chief passage' among the Wisdom texts. This association is certainly valid: the LXX introduces the notion that man's speech is his thought and the mention of a fountain of life; John would readily associate Jesus as the Logos in the believer; and Hanson, Prophetic, 61-62, shows how Pr. 18:4

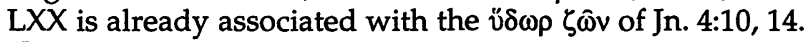

65Goodwin, 'Sources?', 72; including Cant. 4:15; 9:5; Ecclus. 15:3; 24:1921; 51:24; Od.Sol. 30:1-3a; 36:7. Lindars, John, 299-300, too favours Wisdom allusions, while Hanson, Prophetic, 108 ( $c f .110)$, notes, 'if av่ $\tau \hat{v}$ applies to the believer the Wisdom literature, and especially Proverbs, is the place to look for the allusion'. Barrett, Freed and Goodwin also suggest Dt. 8:11; Ps. 114:8; Is. 12:3; 43:3; 44:3; 58:11; Jer. 2:13; 17:13; Joel 4:18; Zc. 14:8. M.-E. Boismard suggests Ps. 78:15-16 and Is. 48:21-22 (Lagrange and Balagué also press for the Isaiah passage). Others have added Nu. 21:16-18 (cf. Jn. 4); Pr. 4:23; Zc. 12:10; 13:1. 
'though John uses the Old Testament, he uses it in a novel manner, collecting its sense rather than quoting'.66

There is no intrinsic problem with this idea. It is not true that, as Barrett says, 'scripture' ( $\dot{\eta} \gamma \rho \alpha \phi \dot{\eta})$ in the Fourth Gospel 'generally refers to a particular passage of scripture';67 it often refers to conflates and can refer to a whole range of scriptures ( $c f$. 7:42). Indeed, Hoskyns suggests that this is not intended as a quotation at all, but as a comment on a passage of scripture. 68 While Goodwin tentatively suggests that John is quoting something as scripture which in fact is not, ${ }^{69}$ John's familiarity with the Jewish scriptures makes it unlikely that he is mistaking something for scripture which clearly is not.

This does not mean, however, that John always works with Jewish scripture-in 17:12 he does not-only from what he accepts as scripture. Nor does this undermine Goodwin's central point, that John is 'capable of changing his sources beyond recognition'. Recourse to a testimonium could absolve John of all responsibility in this respect, but such conjecture is unnecessary; repeatedly John can be seen to adapt Jewish scripture to suit his purposes. Yet Jewish thought frames the immediate context. John 7:34-6 is not so different from the Midrash on Psalm 10:1, 'for three and a half years the Presence announced and had it proclaimed: "Seek the Lord while $\mathrm{He}$ may be found"' followed by the parable of the traveller by $R$. Hanina ${ }^{70}$ moreover, Hanson sees a resemblance between 7:36

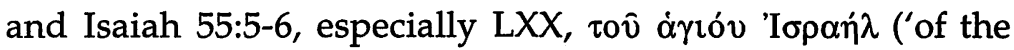
holy one of Israel'; $c f$. Jn. 6:69). ${ }^{71}$

66Barrett, 'Old Testament', 156. Cf. Freed, Quotations, 118, adding, 'It is a spontaneous quotation, perhaps from memory'.

67Barrett, Gospel, 326; cf. Hanson, Prophetic, 109.

${ }^{68}$ Hoskyns, Fourth, 320-23.

${ }^{69}$ Goodwin, 'Sources?', 72. This goes beyond the suggestion of Reim, Studien, 57ff., that John may not know the scripture, as well as of that first proposed by H.J. Holtzmann, Evangelium, Briefe, und Offenbarung des Johannes (Tübingen: Mohr, 1908) 166, that John quotes a now lost scripture.

70W.G. Braude (ed.), The Midrash on the Psalms (YJS 13; New Haven: Yale, 1959) I, 151.

71Hanson, Prophetic, 98, 'It seems probable that John has created the passage 7:32-36 largely out of a scriptural passage, Isaiah 55:5-6'. 
Some, if not all, of the above texts seem to have influenced John's quotation. The only serious attempt to identify a single Old Testament text has been that of Torrey, on the grounds that the Fourth Gospel's written origins were as an Aramaic foundation document ('Grundschrift'). $72 \mathrm{He}$ argues that this passage was originally an Aramaic version of Zechariah 14:8, with its prophecies that living water will flow out from Jerusalem; Torrey suggests that a mistake has taken place in the translation to Greek, so that 'the midst of her (Jerusalem)' (הI, gawwah) was understood as 'the midst (belly) of him' (政2, gawweh). Torrey's case is not wholly convincing. First, that the scripture is a 'badly written' Greek translation of an Aramaic original is merely conjecture. Second, to exalt Jerusalem in this manner would be anathema to any Fourth Gospel Vorlage, however early; even in 4:22-23, the Fourth Gospel's most overtly pro-Jewish text, the significance of Jerusalem (as with all geographical locations) is strenuously undermined. Barrett writes, 'neither in Aramaic nor in Greek was the gospel interested in water flowing out of Jerusalem, but in water flowing out of believers (or Christ) ${ }^{\prime} .{ }^{73}$

It is unfortunate, however, that Zechariah 14:8 is invariably dismissed along with Torrey's argument, since it holds a vital key. Its reference to living water flowing out of Jerusalem had been developed by contemporary Jewish thinking into an eschatological theme of rivers spreading out from the Temple, while Jerusalem itself was regarded, even pre-rabbinically, as the navel of the earth. ${ }^{74}$ Bearing in mind the text's links with Tabernacles, John clearly uses a stylised version of it in which he replaces Jerusalem with something else.

${ }^{72}$ C.C. Torrey, The Four Gospels: A New Translation (London: Hodder \& Stoughton, 1936) 108-11. On this debate, see Schnackenburg, John, I, 105-11.

${ }^{73}$ Barrett, Gospel, 328-29.

${ }^{74}$ E.g. Jub. 8:19 (Mt. Zion is the centre of the navel of the earth); Eze. 38:12; b. Sanh 37a. B.F. Westcott, The Gospel According to St. John (London: J. Clark \& Co., 1958) 69, had originally associated Zc. 14:8 with Jn. 4:10. 
This discussion has invariably led us into Lindar's third area of difficulty: application. Out of whom do the rivers of living water flow, Jesus or the believer? Leaving to one side the fact that the traditional punctuation allows only for the latter, John is not averse to double entendre and neither idea is mutually exclusive. But what could he mean by the former? Perhaps Jesus replaces the Jerusalem of Zechariah 14:8, and the water flowing out of him is the water of the Spirit replacing the water of Torah. But John never uses this imagery elsewhere. Rather, Jesus is the living water, that water flowing out of the believer (e.g. 4:13-14). ${ }^{75}$ Thus it is the latter application that makes eminent Johannine sense. ${ }^{76}$

With John 7:38 being a quotation primarily of Zechariah $14: 8$, though with the help of some of, maybe all, the other suggested scriptures, 77 and part of John's replacement motif (viz., the prophecy transferred from Jerusalem to the believer), ${ }^{78}$ a wealth of Old Testament and Jewish, even

75R.E. Brown argues (The Gospel According to John [AB 29/29A; London: Chapman, 1971], I, 326ff.) that, unlike the well in Jn. 4, the living water here is not for the benefit of the believer, but his point is now well founded. There is no implication per se that the living water is to benefit the passer-by; it signifies the believer as indwelt by the Spirit.

${ }^{76}$ The belief that the traditional punctuation is reconcilable with $\alpha \dot{v} \tau o v$ referring to Christ (e.g. A. Loisy, Le Quatrième Evangile [Paris: Nourry, 1921], 271) despite recourse to the messianic age, is untenable. Those who have $\alpha$ v่ $0 \hat{v}$ refer to the believer include J.B. Cortés, 'Yet Another Look at John 7:37-8', CBQ 29.1 (1967) 75-84; G.D. Fee, 'Once More - John 7:37-9', ExpTim 89 (1977-8) 116-18; Barrett, Gospel, 326-27; Lindars, John, 299.

77The consensus of opinion, including Hanson, Prophetic, 113f. (he adds Ps 40:9b), Brown, Barrett, Loisy, Sanders and Schlatter, suggests Zc. 14:8, Eze. 47:1(-11) and the riven rock (Nu 20:11). Barrett and Brown give $\mathrm{Zc}$. 14:8 pride of place. The frequently cited sacramental connection via 19:34 is only valid if $\alpha$ vंนov refers to Christ. We consider it at best incidental; John certainly makes nothing of it.

${ }^{78}$ M.-E. Boismard, 'De Son Ventre Couleront des Fleuves d'Eau (Jo VII,

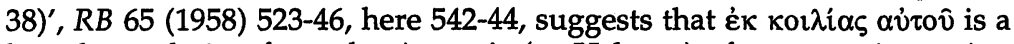
literal translation from the Aramaic (or Hebrew) of a targumic version

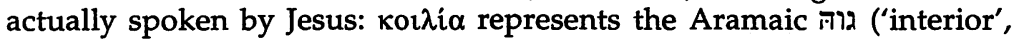
'belly') which, with the preposition מן, Jesus only intended to mean 'out of'. Schnackenburg, John III, 156, accepts this explanation; Hanson, Prophetic, 108-109, 111-12, rejects it. A.T. Hanson, The New Testament 
Eastern (so Lindars) imagery opens up. Much of it centres on the seven or eight day Feast of Tabernacles, the setting of 7:38. Guilding's connecting of the feast-related sectioning and narrative execution of the Fourth Gospel to a Palestinian triennial lectionary cycle, relates this most popular Jewish feast (as shown by the fact that it was simply known as 'the feast', $\dot{\eta}$

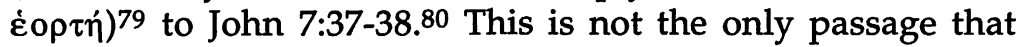
Guilding considers; she also finds significance in the dwelling in huts ( $c f .1: 14$, where the Logos is said to have 'dwelt among us'), in the rite of lamp-lighting ( $c f .8: 12)^{81}$ and in the vintage festival ( $c f .15: 1-16: 24)$. But it is the rite of water-drawing that concerns John 7:37-38.

On each day of the Feast, water drawn from the pool of Siloam was poured into a silver bowl beside the Altar of Holocaust in the Temple, where it would be used for daily libation at the Altar, from where it would flow away, symbolising the day of the Lord when the promise of Ezekiel 47:1-12 would be fulfilled ( $m$. Sukk. 4.9; cf. Zc. 13:1; 14:8). While it is not mentioned in the Old Testament (unless in Zc. 14:8) or by Josephus, Barrett suggests that 'there is no reason to doubt that [this ceremony] was carried out before the destruction of the Temple'; m. Sukk 4.9 (cf. Jos. Ant. 13.372) suggests that it

Interpretation of Scripture (London: SPCK, 1980) 161; Freed, Quotations, 25; prefer recourse to Ps. 40:9b, which the midrash on Ps. 40:8-10 (Braude I, 435) and $b$. Yeb 77a apply to David, and see an allusion to Ps. 40:8-15 in 7:17-19.

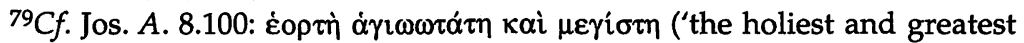
feast'). $m$. Sukk 4.1ff., 5.1ff., give an account of the feast as it would have been observed in the first century. See H. Danby, The Mishnah (Oxford: OUP, 1933) 179-80; Strack \& Billerbeck, Kommentar II, 774.

${ }^{80}$ Aileen Guilding, The Fourth Gospel and Jewish Worship (Oxford: Clarendon, 1960) 104ff. Few, however, remain convinced of her reconstructed lectionary cycle to which John adheres. See M.D. Goulder, The Evangelists' Calendar (London: SPCK, 1978) 101-102; Hanson, Prophetic, 186.

${ }^{81}$ Throughout the week the Court of the Women was kept lit, to symbolise that the day of the Lord would be a day without night (cf. Zc. 14:7; Is. 60:19-20). See m. Sukk 5.2-3. 
may go back to Alexander Jannaeus. 82 The custom of beginning prayers for rain at the Feast also survived $\left(b . T^{\prime} a^{\prime}\right.$ an 1.1$)$, best expressed in the second of the Eighteen Benedictions ('the Power of Rain'), where God, mighty to save, gives life to the dead. 83

Zechariah 12-14 was a central passage in the Feast's liturgy, Zechariah 14 being one of its prophetic Haphtaroth 84 and sometimes read out during it, probably because the Feast is mentioned, together with a reference to rain, in the eschatological setting of $14: 16-17$. That water is the dominant feature in John 7:37-38 while the context is Tabernacles, then, is more than fortuitous. Christ as the living water has a wider Old Testament and Johannine background than the Feast alone, ${ }^{85}$ but the Feast is the pivot on which 7:38 swings. 86 It may even be that John's ambiguity as to what is being quoted is not entirely unintentional; both verses comprise the fulfilment of scripture, as the Feast makes clear. 87 In 7:38 Jesus for the first time pleads with the people of Jerusalem to believe in him. As McHugh says: 'So, in public, in Jerusalem, Jesus offers to all who hear him rivers of life-giving water, flowing from the

82Barrett, Gospel, 327. Josephus describes the feast in Ant. $3.4 / /$ 10.24447 , but perhaps mentions nothing about the custom since he is merely relating what was stipulated as law by Moses.

83S. Singer, The Authorized Daily Prayer Book of the United Hebrew Congregations of the British Empire (London: Eyre \& Spottiswoode, 1912) 44.

${ }^{84}$ H. St. J. Thackeray, The Septuagint and Jewish Worship. A Study in Origins (London, Milford: OUP, 1920) 64-67.

${ }^{85}$ Also see Hoskyns, Fourth, 365.

${ }^{86} \mathrm{Cf}$. Barrett, Gospel, 327. Contra Loisy, Quatrième, 271-72, John is surely interested in the details of Tabernacles. The typical view, as expressed by Hanson, Prophetic, 112, that 'John wishes to present Jesus as the true source of life and Spirit as contrasted with the ritual worship of Judaism', misses the point of John's replacement christology; with the Temple cultus gone, John presents Jesus not as the answer to Judaism but as the answer for Judaism.

${ }^{87} \mathrm{Cf}$. Glasson, Moses, 49: 'It was as though Jesus were claiming to be the fulfilment of what was foreshadowed in these two rites' of water and light. 
Temple, divinely promised for the end-time, the Day of the Lord. The words of Ps 36:9-10 come to mind'.88

There is specific Old Testament Mosaic imagery shared between John 7:37-38, the Feast, and Zechariah 12-14: that of the smitten rock of Exodus 17.89 Glasson, who may give a better picture of this than anyone, argues that in fact all three look forward to the messianic era that would recapitulate the exodus event. 90 In reality, first-century Jews would associate the days of the exodus with the days of the Messiah anyway, and those who saw the water ceremony would think of the promised streams of the messianic age as well as the waters in the desert, the latter being a child of the former.

Thus it was a central characteristic of the Messiah that he would recapitulate Moses' act in providing water too. Ecclus. R. I.9, claiming that both the former and the latter redeemer cause manna to descend, adds that both bring up water. ${ }^{91}$ In Old Testament and later Jewish writings the manna and the water from the rock are often linked together (cf. Ne. 9:15; Ps. 78:20; 105:40-41), and this link is accepted by the early Christians ( $c f .1$ Cor. 10:3-4). ${ }^{92}$ Since John 6 presents Christ as the bread corresponding to the manna, therefore, it is 'not surprising to find in chapter 7 the promise of living water, particularly in the context of the Feast of Tabernacles when the wilderness years were commemorated' .93

That John 7:38 is fundamentally eschatological rather than retrospective 94 - in John 6 Jesus is the eschatological age's promised manna, here he is its promised water, in John 8 he is

${ }^{88} \mathrm{McHugh}$, 'Life', 141.

${ }^{89} \mathrm{Jn}$. 8:12 similarly echoes the pillar of fire (Ex. 13).

90 See Glasson, Moses, ch. 7, 'The Living Water and the Rock'.

91See Martyn, History, 98ff., who also notes the Moses imagery. Cf. W.A. Meeks, The Prophet-King (NovTSup 14; Leiden: Brill, 1967).

92E. Haenchen, A Commentary of the Gospel of John (Eng. trans., Philadelphia: Fortress, 1984) II, 17, has no warrant to link this passage so much with Jn. 7:37-38 that here too Jesus, as the riven rock, must be the source of the water.

${ }^{93}$ Glasson, Moses, 48.

${ }^{94}$ R.H. Lightfoot, St. John's Gospel: A Commentary (Oxford: Clarendon, 1956) 182, similarly emphasises the eschatological significance of Tabernacles. 
its promised light95-shows how John uses both the Old Testament and contemporary Jewish imagery to support his realised eschatology. Jesus is the Messiah, these days here and now are those of the messianic age. No longer 'as the first redeemer was, so shall the latter redeemer be', rather, 'as the first redeemer was, so the latter redeemer is'.

This does not mark the extent of Jewish scripture and imagery in 7:38. With Jesus replacing the lost Temple cultus, John cannot miss the connection with the eschatological Temple of Ezekiel 47:1-11; and the story of the riven rock with its Sinai and exodus associations is hardly below the surface. Moreover, water had a wealth of associations (as well as those already cited, $c f$. Is. 49:10; Ps. 42:3). Living, fresh, flowing

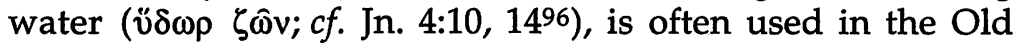
Testament (e.g. Pr. 10:11; 13:14; 16:22), ${ }^{97}$ primarily as a general metaphor for God's activity in quickening his creatures to life (e.g. Ps. 36:10a; Jer. 2:13; Eze. 47:1ff., esp. v. 9), ${ }^{98}$ and it seems likely that John is aware of all these passages. In rabbinic literature, while living water is not a frequent metaphor, water is, and becomes associated with Torah, less commonly with the Holy Spirit. In 1 Enoch $(48: 1 ; 49: 1)$ it is associated with Wisdom. ${ }^{99}$ These metaphors, used in a similar fashion, are also found at Qumran: $1 \mathrm{QH} 8.16$ speaks of a fountain of living water; CD 3.16-17, 6.4-11 states that 'the well is the Law', while the staff is the 'Interpreter of the Law';100 in CD 19.34 water is equated with Torah; and in 1QS 4.20ff. it refers to the Holy Spirit. It is unnecessary to presume any direct influence of Qumran on John or other similar early Christian writings (e.g.

\footnotetext{
95This vindicates our application: Jesus not so much provides the water, he is the water.

${ }^{96}$ Holtzmann, Evangelium, 103, notes John's re-eschatologising tendency, citing Revelation passages, esp. 7:17; 21:6; $22: 1$.

97Hanson, Prophetic, 61, speaks of an embarras de richesse.

98Z.C. Hodges, 'Rivers of Living Water-John 7:37-39', Bsac 136 (1979) $239-48$, suggests that $\pi$ o $\tau \alpha \mu$ oi in Jn. 7:38 may actually be a rendering of the dual נin in the MT.

${ }^{99}$ See Strack \& Billerbeck, Kommentar II, 433-36.

${ }^{100}$ Hanson, Prophetic, 110, is right: the Qumran connection together with John's use of the Well Song in ch. 4 makes its use here, albeit secondary, 'difficult to exclude'.
} 
Rev. 22:17). It is better to see the parallels as further evidence of the pervasiveness of the general Jewish imagery.101 John, like Qumran (and Philo), is well aware of this imagery and puts it to good effect. Jesus, the final expression of God's Torah and Wisdom, is that (living) water.

By its own admission John 7:39 is a later redaction, part of John's explanation of Jesus' words, and has no immediate bearing on v. 38. Nonetheless, it cannot be ignored. At an early point in the Fourth Gospel's development, it equated the Holy Spirit, standing in Jesus' place, with the streams of living water. The theme is thoroughly Jewish; 102 as with the more general theme that the Spirit imparts life (e.g. Gn. 2:7; 6:3; Eze. 37:1-14), perhaps most striking is $G n R$. 70:8 where the waterdrawing of Tabernacles is interpreted as drawing the Holy Spirit. That John uses such imagery is difficult to deny, especially since Zechariah 12-14 was involved in current Jewish eschatological developments of it. ${ }^{103}$ Neither is he alone in this regard; 1 Corinthians 12:13 shows the Christianizing of the same motif by another early Christian writer.

Once again John's interest and familiarity with both Jewish scripture and current Jewish exegetical methods are clear to see; the more one is aware of Tabernacles and its associated imagery, the more one can grasp the depth of John's theological argument at this point.

\footnotetext{
${ }^{101}$ In certain respects Qumranian concepts involving water seem to veer away from John's: while in CD water as Torah gives life, in 1QS 4.20-22 it simply cleanses, a theme lacking in the Gospel (though $c f$. Jn. 13:2-10). See H. Braun, 'Qumran und das Neue Testament', TR $u 28$ (1962) 97-234 (2 vols., Tübingen: Mohr [Siebeck], 1966) 192ff.

102See Strack \& Billerbeck, Kommentar II, 434ff.

${ }^{103}$ Even though the date of the complete Genesis Rab. is second millennium, this motif dates back into Second Temple times. Cf. W. Russell, 'The Holy Spirit's Ministry in the Fourth Gospel', Grace Theological Journal 8.2 (1987) 227-39, 233-34, who explores John's systematic presentation of the Spirit from the perspective of Old Testament messianic expectations.
} 


\section{Conclusion}

This paper has dealt with only two of John's eighteen citations from scripture. Yet a number of things are apparent from this very small sample. First, John makes intensive use of the Jewish scriptures. Indeed, the Jewish scriptures are essential to the major facets of his Gospel: his christology and his polemic. Second, he is well aware of and employs received Jewish exegetical methods. ${ }^{104}$ Moreover, since these passages have a specifically evangelistic element, one of John's purposes in writing is to convince wavering members of the synagogue that Jesus is the Messiah. In short, John's Jewish use of the scriptures demonstrates that he is operating with the conceptual matrix of a thoroughly Jewish self-identity.

104The extent to which John's audience would need to be immersed in a knowledge of the same method is an issue addressed in my Ph.D. thesis for Nottingham University, entitled Is John's Gospel Antisemitic? With Special Reference to His Use of the Old Testament. 